\title{
Field Performance of Xanthosoma sagittifolium L. Schott Minitubers Grown Under the Influence of Poultry Manure and NPK Fertilizers: Changes in Content of Some Secondary Metabolites
}

\author{
Gwan Mofor Elvis ${ }^{1,2^{*}}$ Djeuani Astride Carole ${ }^{1,3} \quad$ Tene Tayo Paul Martial ${ }^{2,4} \quad$ Boudjeko Thaddée $^{2,4}$ \\ Omokolo Ndoumou Denis ${ }^{1}$ \\ 1.Department of Biological Sciences, Laboratory of plant physiology, Higher Teacher Training College (HTTC), \\ University of Yaoundé I, Yaoundé-Cameroon \\ 2.Department of Biochemistry, Faculty of Science, University of Yaoundé I, Yaoundé-Cameroon \\ 3.Department of Plant Biology, Faculty of Science, University of Yaoundé I, Yaoundé-Cameroon \\ 4.Laboratory of Phytoprotection and Plant Valorization, Biotechnology Center, University of Yaounde I, \\ Yaoundé- Cameroon
}

\begin{abstract}
The response of white and red cultivar (cv) cocoyam (Xanthosoma sagittifolium (L.) Schott) minituber seeds to different rates of poultry manure (PM) and NPK (20:10:10) fertilizer was studied under field conditions in the 2017 cropping season on an experimental farm at Ngog Bibega, Mbankomo Sub-division, (outskirsts of Yaounde) Centre region, Cameroon. Treatment combinations comprising of three rates each of poultry manure $\left(0,20\right.$ and $\left.30 \mathrm{t} \mathrm{ha}^{-1}\right)$ and NPK fertilizer $\left(0,120\right.$ and $\left.150 \mathrm{~kg} \mathrm{ha}^{-1}\right)$ were factorized and fitted into a randomized complete block design with three replicates. Physico-chemical analysis of all treatment plots revealed clay loam textures and poultry manure treatment plots significantly $(\mathrm{P}<0.05)$ increased soil $\mathrm{pH}$, organic content, total carbon and cation exchange capacity while NPK treatments significantly $(\mathrm{p}<0.05)$ increased available phosphorus compared to the control treatments. Poultry manure $\left(30 \mathrm{t} \mathrm{ha}^{-1}\right)$ treatments significantly $(\mathrm{P}<0.05)$ enhanced plant height, leaf number and leaf area in both cultivars after 6 months of growth as compared to all other treatments. Under the same treatments of poultry manure $\left(30 \mathrm{t} \mathrm{ha}^{-1}\right)$ the white cultivar plants recorded the most significant mean yield parameters after 9 months of growth. The average tuber number per plant (8), tuber weight $(250 \mathrm{~g})$, tuber length $(14 \mathrm{~cm})$ and tuber girth $(18.5 \mathrm{~cm})$ compared to the red cultivar average yield parameters: tuber number per plant (5.7), tuber weight $(124.7 \mathrm{~g})$, tuber length $(8 \mathrm{~cm})$ and tuber girth $(14.5 \mathrm{~cm})$. Biochemically the application of various treatments of poultry manure and NPK fertilizers significantly $(\mathrm{P}<0.05)$ influenced the changes observed in the secondary metabolites studied. Two months after planting, NPK (150kg $\left.\mathrm{ha}^{-1}\right)$ treatments showed the most significant phenolic content $\left(1.22 \pm 0.13 \mathrm{mg}\right.$ eq catechin. $\left.\mathrm{g}^{-1} \mathrm{FW}\right)$ and flavonoid content $\left(1.08 \pm 0.16 \mathrm{mg} \mathrm{g}^{-1} \mathrm{FW}\right)$ in white $\mathrm{cv}$ cocoyam plants. After 6 months of growth, the poultry manure $(30 \mathrm{t}$ $\left.\mathrm{ha}^{-1}\right)$ treatments recorded the most significant protein content $\left(5.04 \pm 0.38 \mathrm{mg}\right.$ eq BSA.g $\left.{ }^{-1} \mathrm{FW}\right)$ and peroxidase activity $\left(4.89 \pm 1.36 \mathrm{UE} \mathrm{min}^{-1}\right)$ in white cv cocoyam plants while red cv cocoyam plants had the most significant glucanase activity $\left(9.33 \pm 1.17 \mathrm{mg}\right.$ eq glucose $\left.\mathrm{g}^{-1} \mathrm{FW}\right)$. NPK $\left(150 \mathrm{~kg} \mathrm{ha}^{-1}\right)$ treatments in white cv cocoyam plants recorded the most significant polyphenol oxidase activity (4.99 \pm 0.10 in D330 nm-1 $\left.\mathrm{min}^{-1} \mathrm{UE}^{-1} \mathrm{~g}^{-1} \mathrm{FW}\right) 6 \mathrm{months}$ after planting.
\end{abstract}

Keywords: Xanthosoma sagittifolium L. Schott; Minitubers; cation exchange capacity; Poultry manure; NPK fertilizers; yield parameters and secondary metabolites.

DOI: $10.7176 / \mathrm{JBAH} / 9-20-05$

Publication date:October $31^{\text {st }} 2019$

\section{Introduction}

Cocoyam (Xanthosoma sagittifolium L. Schott, Araceae) is a herbaceous plant cultivated in tropical and subtropical regions for its edible tubers and leaves. Cocoyam tubers and leaves are essentially rich in sugars, proteins, vitamins and mineral salts (Sefa \& Sackey, 2004). It covers the food needs of more than 200 million persons in the tropical and subtropical regions and more than 400 million persons worldwide (Onokpise et al., 1999). It occupies the sixth position worldwide with an annual production of 0.45 million metric tonnes (FAO stat, 2006) and the second in Cameroon after cassava (Mannihot esculenta) in terms of tuber production. The National Programme on Roots and Tubers (NPRT) was launched in Cameroon in 2005. Annual production of cocoyam has since increased from 1,240,037 tons in 2005 to 2,000,000 tons (NPRT stat, 2013) with projections of 3000,000 tons by 2020 .

In Cameroon, the unavailability of healthy seeds to farmers has affected the National production rate. The infestation of seeds is due to several viral, fungal and bacterial diseases (FAO stat, 2008;Chen \& Adams, 2001;Perneel et al., 2006). Otherwise, the lack of cocoyam seeds can be justified by the fact that cocoyam usually 
propagates vegetatively from tuber fragments, this increases the dissemination of many pathogens which cause rot disease in cocoyam such as Pythium myriotylum (Perneel et al., 2006;Boudjeko et al., 2005) ,Fusarium oxysporum and Fusarium solani (Ubalua et al., 2008;Anele \& Nwawuisi, 2008) and Dasheen mosaic virus that is found in the leaves, corm and cormels (Chen \& Adams, 2001). To overcome such problems, efforts have been made to improve the application of tissue culture technology to cocoyam production through in vitro regeneration of cocoyam plants using biotechnology (Omokolo et al., 2003). Nowadays the production of cocoyam minitubers can be considered as a revolution like the production of potato minitubers. Cocoyam minitubers could be used as an alternative for basic seeds produced through plantlets obtained in vitro (Djeuani et al., 2014).

Inspite of the important role played by cocoyam in feeding, another major factor which accounts for low production is the increasing decline in soil fertility levels and lack of soil management practices for continuous cocoyam cultivation(Agbede et al., 2014). Low activity clays characterize tropical soils and the magnitude of nutrient depletion especially in Africa's agricultural production systems is enormous(Stoorvogel, 1990). This depletion of soil fertility is widely recognized as the major cause of low food crop production in sub-Saharan Africa (Sanchez \& Jama, 2000). External fertilising agents to agricultural production systems include mineral fertilisers such as urea, NPK, ammonium nitrate, sulfates, and phosphates; organic fertilisers such as animal manures, composts, and biosolids. The use of mineral fertilizers in sub-Saharan Africa is limited by the lack of purchasing power and scarcity of the product in the smallholder sectors while their continuous use can also lead to a decline in soil organic manure (SOM) by enhancing its decomposition (Giller et al., 2009), making SOM a critical nutrient source. The use of organic and mineral fertilizers are the two major and common ways in which soils are managed since the extinction of shifting cultivation as well as reduction in bush fallow periods (Makinde et al., 2011). The impact of increased use of mineral fertilizers on crops has been high but the resulting soil physical degradation, increased soil acidity and soil nutrient imbalance, resulting in reduced crop yield (Ojeniyi, 2000;Mbah \& Mbagwu, 2006) escalating cost and unavailability of mineral fertilizers (Surge et al., 2011) have drawn the attention of researchers back to the use of organic manures. Organic manures contain humic substances which play a vital role in soil fertility and plant nutrition. Plants grown on soils which contain adequate humin, humic adds (HAs), and fulvic adds (FAs) are less subject to stress, are healthier, produce higher yields; and the nutritional quality of harvested foods and feeds are superior. These organic manures like poultry manure are cheaper, readily available and affordable for soil fertility management and improvement in crop yield. The availability of inorganic nitrogen in particular has the potential to influence the synthesis of secondary plant metabolites, proteins, and soluble solids(Baneerjee \& Mondal, 2012). Different manures (fish, pigeon and cow) and synthetic fertilizers (nitrogen) have been shown to influence some biochemical activities like phenolic constituents of plants (Tugba et al., 2014). The quantity of phenolic compounds present in a given species of plant material varies with a number of factors such as cultivar, environmental conditions, cultural practices postharvest storage and processing (Chandrasekara \& Kumar, 2016). Cocoyam responds very well to input of fertilizer whether organic or inorganic as reported by several workers (Hota et al., 2014;Ogbonna \& Nwaeze, 2012;Ojeniyi et al., 2013). It has a high requirement for potassium like all other tuber crops (Obigbesan, 1980). In tuber crops, potassium plays a vital role in the movement of sugars produced in the leaf by photosynthesis to the tubers where the sugars are converted to starch ( Abd El Latif et al., 2011) Potatoes require high amounts of potassium $(\mathrm{K})$ and nitrogen $(\mathrm{N})$ fertilizers for optimum growth, production and tuber quality (Al- Moshileh et al., 2005).

Against the above background, this study was carried out to: (1) Determine the seed potential of the white and red cultivar cocoyam (Xanthosoma sagittifolium L. Schott) minitubers under different fertilizer treatments (Poultry manure and NPK 20:10:10) (2) Evaluate the effects of these fertilizer treatments on the changes in the content of some secondary metabolites in the leaves of white and red cocoyam (Xanthosoma sagittifolium) cultivars during growth.

\section{Materials and methods}

\subsection{Site location}

A field trial was conducted to study the performance of Xanthosoma sagittifolium minituber seeds as influenced by poultry manure and NPK fertilizer during the 2017 cropping season on an experimental farm at Ngog Bibega, Mbankomo Sub-division, (Outskirsts of Yaoundé) Centre region, Cameroon, located at latitude $3^{\circ} 49^{\prime} 52.54^{\prime \prime} \mathrm{N}$ and longitude $11^{\circ} 27^{\prime} 15.79^{\prime \prime} \mathrm{E}$ and $714 \mathrm{~m}$ above sea level. The area is characterized as a humid rainforest zone and the soil is clay loam. The total annual rainfalls for 2017 was $1902.8 \mathrm{~mm}$ while the total rainfalls during the period of experimentation (April to December) for 2017 was $1775.6 \mathrm{~mm}$.

\subsection{Materials}

The planting material consisted of white and red cultivars of X. sagittifolium minituber seeds of mean weight $38 \mathrm{~g}$ produced from acclimatised vitroplants under the shed in the plant physiology Laboratory of the Higher 
Teachers Training college (HTTC), University of Yaoundé I. Yaoundé, Cameroon (Djeuani et al., 2014, 2017). The Poultry manure was obtained from Henri et Freres Poultry farm Yaoundé, Cameroon while the NPK fertilizer (20:10:10) was obtained from the fertilizer unit of the Centre Regional Delegation of Agriculture and Rural Development, Yaoundé, Cameroon.

\subsection{Experimental design, treatments, soil and morphological analysis during growth and yield of cocoyam plants}

The experiment was a $4 \times 2$ factorial arrangement in a randomized complete block design and replicated three times. The site was ploughed, ridged and marked out into two main blocks, one for each cultivar. Each of these main blocks was further subdivided into 3 sub blocks which represent the three replicates. Each sub block was divided into five experimental plots, thus a total of fifteen plots were used for cultivar. Each gross plot measured $4 \mathrm{~m} \times 3 \mathrm{~m}\left(12 \mathrm{~m}^{2}\right)$ with a net plot of $2 \mathrm{~m} \times 2 \mathrm{~m}$. Soil samples were collected with soil auger at a depth of 0 to $20 \mathrm{~cm}$ from different locations of the site and bulked into composite sample. The composite soil sample was air dried, passed through $2 \mathrm{~mm}$ sieve, and then analyzed for its physicochemical properties before planting and after harvest (Table1). Particle size distribution was performed to determine the soil textural class using hydrometer method as described by Gee \& Bauder, 1986. Soil pH was determined in distilled water and potassium chloride solution using $\mathrm{pH}$ meter (Mclean, 1982). Soil nitrogen was determined by Macro-Kjeldahl digestion method (Bremner, 1982). Exchangeable Ca and $\mathrm{Mg}$ were obtained by the complexometric titration method of Chapman, 1982, and exchangeable $\mathrm{Na}$ and $\mathrm{K}$ were determined by flame photometer. Cation Exchange Capacity (CEC) was determined by modified ammonium acetate method of Chapman, 1982 while available P determined by Bray II method (Bray, 1945). The treatments comprised three rates each of application of Poultry Manure $(0,20$, and 30 $\mathrm{t}$ ha-1) and NPK fertilizer $(0,120$, and $150 \mathrm{~kg}$ ha-1). A total of fifteen treatment combinations and three replications were used. The Poultry manure was incorporated into the soils on the experimental plots in a single application based on the treatment combinations, at 2 weeks before planting to ease decomposition, while the NPK fertilizer was applied to the cocoyam stands according to treatment allocation at 4 weeks after planting (WAP) using the ring placement method. Each minituber was planted per hole at a depth of $15 \mathrm{~cm}$ and at a spacing of $0.5 \mathrm{~m} \mathrm{x} 1.0 \mathrm{~m}$ resulting to about twenty-five plants per plot and a total of 375 plants per cultivar. All plots were kept weed free by manual weeding. Five cocoyam plants were randomly selected from each of the net plots, tagged and then used for the determination of average plant height $(\mathrm{cm})$, average number of leaves, and average leaf area at 1, 2, 3,4,5,6,7, and 8 months after planting (MAP). Yield parameters like length $(\mathrm{cm})$ and girth $(\mathrm{cm})$ of tubers, number of tubers per plant, and tuber weight $(\mathrm{g})$ were assessed after 9 months at physiological maturity. The leaf area was determined using the formula of (Biradar, 1982) as: Leaf Area of Cocoyam $=0.917(\mathrm{LW})$. Where $\mathrm{L}$ and $\mathrm{W}$ are length and width of the cocoyam leaf.

\subsection{Biochemical analysis}

Biochemical analyses consisted of extraction and assay of total soluble proteins, peroxidases, $\beta-1,3$ glucanases, Polyphenoloxidases, Total Phenol content and flavonoid content in the leaves each month for 6 months after planting.

\subsubsection{Protein Content}

Proteins were extracted according to the modified method of Pirovani, 2008. $1 \mathrm{~g}$ of leaves were ground in chilled mortar with $5 \mathrm{~mL}$ of Tris- Maleate buffer $(10 \mathrm{mM} \mathrm{pH} \mathrm{7.2).} \mathrm{The} \mathrm{crude} \mathrm{homogenate} \mathrm{was} \mathrm{centrifuged} \mathrm{for} 25 \mathrm{~min}$ at $10000 \mathrm{~g}$ and $4^{\circ} \mathrm{C}$ after incubation. The supernatant was removed and used as crude extract for protein and enzymes assays. Proteins were quantified according to method described by Bradford, 1976. $10 \mu 1$ of extract were added to $490 \mu \mathrm{l}$ of distilled water and $500 \mu \mathrm{l}$ of Bradford reagent. The mixture was incubated at $25^{\circ} \mathrm{C}$ in darkness for $15 \mathrm{~min}$ and OD of protein determined at $595 \mathrm{~nm}$. The protein content was expressed in mgequivalent of BSA per Fresh Weight (Bradford, 1976).

\subsubsection{Peroxidase Assay}

Peroxidase assay in protein extract was done according the modified method of Baaziz et al., 1994. The reaction medium contained $925 \mu \mathrm{l}$ of Tris- Maleate buffer $(10 \mathrm{mM} \mathrm{pH} \mathrm{7.2,} \mathrm{containing} 1 \mathrm{~g}$ gaïacol), $25 \mu 1$ of protein extract and $50 \mu \mathrm{l}$ of $\mathrm{H}_{2} \mathrm{O}_{2}(10 \%)$. The mixture was incubated for $3 \mathrm{~min}$ at $25^{\circ} \mathrm{C}$. Peroxidase activity was determined following the formation of tetragaïacol at $470 \mathrm{~nm}$. Peroxidase activity was expressed in enzyme units per Fresh Weight (FW).

\subsection{3. $\beta-1,3$ Glucanase Assay}

The activity of $\beta$-1,3-glucanases was evaluated in the protein extract according to the modified method described by Leelasuphakul, 2006. The reaction mixture contained $90 \mu \mathrm{l}$ of sodium acetate buffer $(0.1 \mathrm{M}, \mathrm{pH} 4 \mathrm{containing}$ $25 \mathrm{mg} / \mathrm{L}$ of Laminarin), $10 \mu \mathrm{l}$ of protein extract incubated for $10 \mathrm{~min}$ at $40^{\circ} \mathrm{C} .200 \mu \mathrm{l}$ of $2 \mathrm{M} \mathrm{HCl}$ is used to stop the reaction. The OD was read at 540nm. $\beta$-1,3-glucanase activity was expressed in $\mu$ mole of glucose released $/ \mathrm{min} / \mathrm{g}$ of Fresh Weight. 


\subsubsection{Polyphenol oxidase Assay}

Polyphenol oxidase assay was determined in the protein extract according to the method of Vankammenn \& Broumer, 1964. The reaction mixture contained $500 \mu \mathrm{l}$ of phosphate buffer $(0.66 \mathrm{M}, \mathrm{pH} 7), 150 \mu 1$ of catechine and $35 \mu \mathrm{l}$ of protein extract incubated at $25^{\circ} \mathrm{C}$ for $30 \mathrm{~s}$. The change in absorbance was read after $5 \mathrm{~min}$ at $330 \mathrm{~nm}$. Polyphenol oxidase activity was expressed in $\mathrm{D}_{330 \mathrm{~mm}} / \mathrm{min} / \mathrm{UE} / \mathrm{g}$ of Fresh Weight (FW)

\subsubsection{Total Phenol Content}

Phenolic compounds were extracted according to the modified method of Boudjeko et al., 2007. $1 \mathrm{~g}$ of leaves of cocoyam was ground in chilled mortars with $5 \mathrm{ml}$ of $80 \%(\mathrm{v} / \mathrm{v})$ methanol at $4{ }^{\circ} \mathrm{C}$. After incubation, tubes were centrifuged thrice at $7000 \mathrm{~g}$ for $30 \mathrm{~min}$, supernatants were collected each time. Mixture of the three supernatants constituted the crude extract. Total phenols were quantified using the method described by Marigo, $1973.10 \mu 1$ of alcoholic extract were added to $500 \mu \mathrm{l}$ of distilled water, Folin-Ciocalteu reagent $(75 \mu 1)$ and $500 \mu 1$ of sodium carbonate $(20 \%)$. The mixture was incubated at $40^{\circ} \mathrm{C}$ for $20 \mathrm{~min}$ and the blue color was determined at $760 \mathrm{~nm}$. The content of soluble phenolic was expressed in mg-equivalent of gallic acid per Fresh Weight (FW).

\subsubsection{Flavonoid Content}

Flavonoid content was determined according to the modified method of Kramling, 1969. The reaction medium contains $400 \mu \mathrm{l}$ of phenol extract, $200 \mu \mathrm{l}$ of $\mathrm{HCl}(50 \%), 200 \mu \mathrm{l}$ of Formaldehyde $(8 \mathrm{mg} / \mathrm{L})$ incubated at $4^{\circ} \mathrm{C}$ for $15 \mathrm{~min}$. The mixture was centrifuged at $3000 \mathrm{~g}$ for $5 \mathrm{~min}$ and the supernatant collected. The supernatant was then used to assay non flavonoid compounds according to the method described by Marigo, 1973. Flavonoid content was then determined using the following formula:

$$
\mathrm{T}_{\text {flavonoids }}=\mathrm{T} \text { total phenol }-\mathrm{T}_{\text {non flavonoids }}
$$

\section{Results}

\subsection{Soil analyses before planting and after harvest}

Physical analysis of the sand, clay and silt content of the soil on the different treatment plots before planting and after harvest on our experimental farm illustrated a clay loam textural class. (Table 1). Chemically, before planting the soil was slightly acidic ( $\mathrm{pH} \mathrm{5.6)}$ and both poultry manure treatments (20t.ha ${ }^{-1}$ and $30 \mathrm{t} \mathrm{ha}^{-1}$ ) after harvest significantly reduced soil acidity ( $\mathrm{pH} 6.6$ and pH 6.9) (Table 2). Poultry manure treatments $\left(20 \mathrm{t} \mathrm{ha}^{-1}\right.$ and $30 \mathrm{tha}^{-1}$ ) significantly increased organic and carbon content and also recorded the highest cation exchange capacity values as compared to the other treatments. (Table 2).

\subsection{Evaluation of the growth parameters of $X$. sagittifolium plants under different treatments}

All growth parameters (plant height, number of leaves plant ${ }^{-1}$ and leaf area) analysed were generally more significant in the white cultivar cocoyam (white cv) plants than in the red cultivar cocoyam (red cv) plants for all treatments. The poultry manure treatments $\left(30 \mathrm{tha}^{-1}\right)$ showed the most significant increase in all growth parameters analysed from two months after planting to six months after planting among all treatments meanwhile within the same growth period the control treatments ( $0 \mathrm{t}$ of Poultry manure ha-1 and $0 \mathrm{~kg}$ of NPK ha-1) recorded the least increase in average plant height and leaf area for both white and red cultivars of the cocoyam plants. At six months after planting white cv cocoyam plants treated poultry manure $\left(30 \mathrm{t} \mathrm{ha}^{-1}\right)$ showed the most significant growth in terms of average height $(86 \mathrm{~cm})$ (Table 3, Fig 1.) followed by an average height of $77 \mathrm{~cm}$ for cv red cocoyam plants treated with poultry manure(30tons/ha). (Table 4, Fig 1.). The cv red cocoyam plants showed no significant difference in the average number of leaves for all the different treatments throughout the growth period (Table 4.) meanwhile a significant average number of leaves was recorded (6) after six months of growth for white cv cocoyam plants treated with poultry manure $\left(30 \mathrm{t} \mathrm{ha}^{-1}\right)$ ( Table 3$)$. White $\mathrm{cv}$ plants treated with poultry manure $\left(30 \mathrm{t} \mathrm{ha}^{-1}\right)$ after six months of growth recorded the most significant average leaf area $\left(0.88 \mathrm{~m}^{2}\right)$ (Table 3 ) while red cv cocoyam plants treated with poultry manure $\left(30 \mathrm{t}^{\mathrm{h}} \mathrm{h}^{-1}\right)$ recorded an average leaf area of $0.069 \mathrm{~m}^{2}$ after six months of growth. (Table 4)

\subsection{Evaluation of yield parameters of cocoyam under different treatments}

After a period of 9 months the yield parameters were assessed. The four yield parameters (tuber number plant ${ }^{-1}$, tuber weight, tuber length and tuber girth) analysed after harvest were generally greater in white cv cocoyam plants than in red cv cocoyam plants for all treatments. Poultry manure treatments $\left(30 \mathrm{t} \mathrm{ha}^{-1}\right)$ showed the most significant yield parameters while the control treatments (0tons of Poultry manure ha ${ }^{-1}$ and $0 \mathrm{~kg}_{\text {of NPK ha }}{ }^{-1}$ ) had the least yield parameters for both cultivars. White $\mathrm{cv}$ plants treated with poultry manure $\left(30 \mathrm{t} \mathrm{ha}^{-1}\right)$ recorded an average tuber number per plant of 8 , an average tuber weight of $250 \mathrm{~g}$, an average tuber length of $14 \mathrm{~cm}$, and an average girth of $18.5 \mathrm{~cm}$ (Table 5 and Fig 2) meanwhile red cv plants treated with poultry manure $\left(30 \mathrm{t} \mathrm{ha}^{-1}\right)$ recorded 5.7 as average tuber number per plant, $124.7 \mathrm{~g}$ as average tuber weight, $8 \mathrm{~cm}$ as average tuber length and $14.5 \mathrm{~cm}$ as average tuber girth.( Table 6 and Fig 2). 


\subsection{Evaluation of some biochemical parameters}

After 6 months of growth, the treatment poultry manure $\left(30 \mathrm{t}^{\mathrm{h}} \mathrm{a}^{-1}\right)$ recorded the most significant protein content $\left(5.04 \pm 0.38 \mathrm{mg}^{\mathrm{eq} \mathrm{BSA} \mathrm{g}}{ }^{-1} \mathrm{FW}\right)$ for white $\mathrm{cv}$ cocoyam plants followed by the same treatments for red $\mathrm{cv}$ $\left(4.11 \pm 0.52 \mathrm{mg} \mathrm{eq} \mathrm{BSA} \mathrm{g}^{-1} \mathrm{FW}\right)$. The Control White cv plants $\left(0\right.$ tons of Poultry manure ha- ${ }^{-1}$ and $0 \mathrm{~kg}$ of NPK ha$\left.{ }^{1}\right)$ had the least protein content $\left(2.56 \pm 0.29 \mathrm{mg} \mathrm{eq} \mathrm{BSA} \mathrm{g}^{-1} \mathrm{FW}\right)$ while there was no significant difference for the Control and NPK $\left(150 \mathrm{~kg} \mathrm{ha}^{-1}\right)$ treatments in red cv plants after 6 months of growth. (Fig.3A).

Peroxidase activity increased in the three treatments (Control, Poultry manure $30 \mathrm{t} \mathrm{ha}^{-1}$ and NPK $150 \mathrm{~kg} \mathrm{ha}^{-1}$ ) for white cv plants from 2 months after planting to six months after planting with Poultry manure $30 \mathrm{tha}^{-1}$ recording the most significant value of $4.89 \pm 1.36 \mathrm{UE} \mathrm{min}^{-1}$ at 6 months. The Control, and NPK $150 \mathrm{~kg} \mathrm{ha}{ }^{-1}$ treatments for red cv plants recorded an increase in peroxidise activity between 2 and 4 months after planting, followed by a significant decrease at 6 months (Fig.3B)

The most significant value of glucanase activity was observed in red cv cocoyam plants treated with Poultry manure $\left(30 \mathrm{t} \mathrm{ha}^{-1}\right), 9.33 \pm 1.17 \mathrm{mg}$ eq glucose $\mathrm{g}^{-1} \mathrm{FW}$ meanwhile white cv cocoyam plants treated with Poultry manure $\left(30 \mathrm{t} \mathrm{ha}^{-1}\right)$, recorded $7.36 \pm 0.28 \mathrm{mg}^{2}$ eq glucose $\mathrm{g}^{-1} \mathrm{FW}$ after six months of planting. The least value for glucanase activity was seen in red cv plants treated with NPK $\left(150 \mathrm{~kg} \mathrm{ha}^{-1}\right), 1.34 \pm .24 \mathrm{mg}$ eq glucose $\mathrm{g}^{-1} \mathrm{FW}$ after 4 months of planting (Fig.4A).

After 6 months of growth, polyphenol oxidase activity was most significant in $\mathrm{Cv}$ white cocoyam plants treated with NPK $\left(150 \mathrm{~kg} \mathrm{ha}^{-1}\right), 4.99 \pm 0.10$ in D330 $\mathrm{nm}^{-1} \mathrm{~min}^{-1} \mathrm{UE}^{-1} \mathrm{~g}^{-1} \mathrm{FW}$ while the red cv Control, Poultry manure $\left(30 \mathrm{t} \mathrm{ha}^{-1}\right)$ and NPK $\left(150 \mathrm{~kg} \mathrm{ha}^{-1}\right)$ treatments showed no significant difference in polyphenol oxidase Red cv cocoyam plants treated with Poultry manure $\left(30 \mathrm{th}^{-1}\right)$ recorded a polyphenol oxidase activity of $4.39 \pm 0.33$ in D330 $\mathrm{nm}^{-1} \mathrm{~min}^{-1} \mathrm{UE}^{-1} \mathrm{~g}^{-1} \mathrm{FW}$ after 4 months of planting (Fig.4B).

NPK $\left(150 \mathrm{~kg} \mathrm{ha}^{-1}\right)$ treatments recorded the most significant values in phenol contents in both cultivars, white cv cocoyam plants had $1.22 \pm 0.13 \mathrm{mg}$ eq catechin $\mathrm{g}^{-1} \mathrm{FW}$ and red cv cocoyam plants had $1.12 \pm 0.11 \mathrm{mg}$ eq catechin $\mathrm{g}^{-1} \mathrm{FW}$ after 2 months of planting. The white cv cocoyam plants showed no significant difference in phenolic contents in the Control, Poultry manure $\left(30 \mathrm{t} \mathrm{ha}^{-1}\right)$ and NPK $\left(150 \mathrm{~kg} \mathrm{ha}^{-1}\right)$ treatments after 4 months of planting (Fig.5A).

Flavonoid content was greatest at 2 months after planting in red cv cocoyam plants treated with NPK $\left(150 \mathrm{~kg} \mathrm{ha}^{-1}\right), 1.08 \pm 0.16 \mathrm{mg} \mathrm{g}^{-1} \mathrm{FW}$ while white $\mathrm{cv}$ cocoyam plants treated with Poultry manure $\left(30 \mathrm{t} \mathrm{ha}^{-1}\right)$ also recorded a significant flavonoid content value of $0.96 \pm 0.03 \mathrm{mg} \mathrm{g}^{-1} \mathrm{FW}$ after 6 months of growth. The least flavonoid content value was recorded by the control red cv cocoyam plants, $0.06 \pm 0.01 \mathrm{mg} \mathrm{g}^{-1} \mathrm{FW}$ after $6 \mathrm{months}$ of growth (Fig 5B)

Table 1. Physical analyses of soil before planting and after harvest

\begin{tabular}{|c|c|c|c|c|c|c|}
\hline \multirow{2}{*}{$\begin{array}{c}\text { Physical } \\
\text { properties } \\
(\%)\end{array}$} & \multirow{2}{*}{$\begin{array}{c}\text { Farm before } \\
\text { planting }\end{array}$} & \multicolumn{5}{|c|}{ Treatments plots after harvest } \\
\hline & & Control & $\begin{array}{c}\text { Poultry } \\
\text { manure } \\
\left(20 \mathrm{t} \mathrm{ha}^{-1}\right)\end{array}$ & $\begin{array}{l}\text { Poultry } \\
\text { manure } \\
\left(30 \mathrm{t} \mathrm{ha}^{-1}\right)\end{array}$ & $\begin{array}{c}\text { NPK } \\
\left(120 \mathrm{~kg} \mathrm{ha}^{-}\right. \\
1)\end{array}$ & $\begin{array}{c}\text { NPK } \\
(150 \mathrm{~kg} \mathrm{ha} \\
1)\end{array}$ \\
\hline Moisture content & 3.47 & 3.07 & 4.38 & 5.39 & 3.72 & 3.77 \\
\hline Sand & 29.3 & 28.3 & 29.8 & 29.1 & 29.2 & 28.8 \\
\hline Silt & 35.6 & 35.5 & 34.8 & 35.3 & 35.6 & 35.4 \\
\hline Clay & 35.0 & 36.1 & 35.3 & 35.5 & 35.1 & 35.7 \\
\hline Textural class & Clay loam & $\begin{array}{l}\text { Clay } \\
\text { loam }\end{array}$ & Clay loam & Clay loam & Clay loam & Clay loam \\
\hline
\end{tabular}


Table 2. Chemical analyses of soil before planting and after harvest

\begin{tabular}{|c|c|c|c|c|c|c|c|}
\hline \multirow{2}{*}{\multicolumn{2}{|c|}{ Chemical properties }} & \multirow{2}{*}{$\begin{array}{c}\text { Farm before } \\
\text { planting }\end{array}$} & \multicolumn{5}{|c|}{ Treatments plots after harvest } \\
\hline & & & Control & $\begin{array}{l}\text { Poultry manure } \\
\left(20 \mathrm{t}^{\left.-h^{-1}\right)}\right.\end{array}$ & $\begin{array}{l}\text { Poultry } \\
\text { manure } \\
\left(30 \mathrm{t} \mathrm{ha}^{-1}\right)\end{array}$ & $\begin{array}{c}\text { NPK } \\
(120 \mathrm{~kg} \\
\left.\mathrm{ha}^{-1}\right)\end{array}$ & $\begin{array}{c}\text { NPK } \\
(150 \mathrm{~kg} \\
\left.\mathrm{ha}^{-1}\right) \\
\end{array}$ \\
\hline $\mathrm{pH}$ in Water & & 5.6 & 5.5 & 6.6 & 6.9 & 5.6 & 5.4 \\
\hline $\mathrm{pH}$ in $\mathrm{KCl}$ & & 4.4 & 4.2 & 6.4 & 6.8 & 4.7 & 4.4 \\
\hline Organic matter & & 23.44 & 21.75 & 48.31 & 55.85 & 23.41 & 21.49 \\
\hline Total N $(\mathrm{g} / \mathrm{kg})$ & & 1.1 & 1.1 & 1.4 & 1.7 & 1.5 & 1.6 \\
\hline Total C $(\mathrm{g} / \mathrm{kg})$ & & 13.44 & 12.61 & 28.02 & 32.40 & 13.73 & 12.26 \\
\hline Available P (m & & 4.57 & 3.91 & 57.84 & 94.04 & 113.5 & 129.9 \\
\hline $\begin{array}{l}\text { Exchangeable } \\
(\mathrm{cmol} / \mathrm{kg})\end{array}$ & $\mathrm{Ca}$ & 1.6 & 1.62 & 1.96 & 2.39 & 1.91 & 1.99 \\
\hline $\begin{array}{l}\text { Exchangeable } \\
(\mathrm{cmol} / \mathrm{kg})\end{array}$ & $\mathrm{Mg}$ & 0.75 & 0.69 & 0.81 & 1.03 & 0.75 & 0.81 \\
\hline $\begin{array}{l}\text { Exchangeable } \\
(\mathrm{cmol} / \mathrm{kg})\end{array}$ & $\mathrm{K}$ & 0.08 & 0.09 & 0.14 & 0.29 & 0.19 & 0.23 \\
\hline $\begin{array}{l}\text { Exchangeable } \\
(\mathrm{cmol} / \mathrm{kg})\end{array}$ & $\mathrm{Na}$ & 0.10 & 0.10 & 0.49 & 0.53 & 0.21 & 0.31 \\
\hline $\begin{array}{l}\text { Cation } \\
\text { capacity }(\mathrm{cmol} /\end{array}$ & lange & 5.0 & 5.0 & 6.0 & 6.0 & 5.6 & 5.6 \\
\hline
\end{tabular}

Table 3. Growth parameters of white $\mathrm{cv} X$. sagittifolium plants

\begin{tabular}{|c|c|c|c|c|c|c|c|c|c|c|c|c|}
\hline \multirow[b]{2}{*}{ Treatment } & \multicolumn{4}{|c|}{ Average plant height $(\mathrm{cm})$} & \multicolumn{4}{|c|}{ Average number of leaves } & \multicolumn{4}{|c|}{ Average leafarea $\left(\mathrm{m}^{2}\right)$} \\
\hline & 2 map & 4map & 6map & 8 map & 2 map & 4map & 6map & 8map & 2map & 4map & 6map & 8 map \\
\hline Control & $35^{\mathrm{e}}$ & $42^{\mathrm{e}}$ & $55^{\mathrm{e}}$ & $25^{\mathrm{e}}$ & $2^{\mathrm{a}}$ & $3^{\mathrm{ab}}$ & $2^{c}$ & $1^{\mathrm{a}}$ & $0.031^{\mathrm{d}}$ & $0.021^{\mathrm{e}}$ & $0.025^{\mathrm{e}}$ & $0.002^{\mathrm{e}}$ \\
\hline PM1 & $70^{b}$ & $73.7^{\circ}$ & $77^{b}$ & $55^{\mathrm{b}}$ & $3^{\mathrm{a}}$ & $4^{\mathrm{ab}}$ & $5^{\mathrm{ab}}$ & $2^{\mathrm{a}}$ & $0.042^{b}$ & $0.053^{\mathrm{b}}$ & $0.072^{\mathrm{b}}$ & $0.021^{\mathrm{d}}$ \\
\hline PM2 & $80^{\mathrm{a}}$ & $86^{\mathrm{a}}$ & $86^{\mathrm{a}}$ & $62^{\mathrm{a}}$ & $4^{\mathrm{a}}$ & $5^{\mathrm{a}}$ & $6^{\mathrm{a}}$ & $3^{\mathrm{a}}$ & $0.051^{\mathrm{a}}$ & $0.067^{\mathrm{a}}$ & $0.088^{\mathrm{a}}$ & $0.031^{\mathrm{a}}$ \\
\hline NPK1 & $40^{\mathrm{d}}$ & $47.7^{d}$ & $60^{d}$ & $39^{d}$ & $2^{\mathrm{a}}$ & $2^{\mathrm{b}}$ & $3^{\mathrm{bc}}$ & $1^{\mathrm{a}}$ & $0.033^{\mathrm{d}}$ & $0.042^{\mathrm{d}}$ & $0.056^{\mathrm{d}}$ & $0.025^{\mathrm{c}}$ \\
\hline NPK2 & $50^{c}$ & $60^{c}$ & $70^{c}$ & $45^{\mathrm{c}}$ & $4^{\mathrm{a}}$ & $4^{\mathrm{a}}$ & $3^{\mathrm{bc}}$ & $1^{\mathrm{a}}$ & $0.039^{c}$ & $0.048^{\mathrm{c}}$ & $0.061^{\mathrm{c}}$ & $0.028^{b}$ \\
\hline Significance & $*$ & $*$ & $*$ & $*$ & $\mathrm{NS}$ & $*$ & $*$ & NS & $*$ & $*$ & $*$ & $*$ \\
\hline
\end{tabular}

KEY: map $=$ months after planting, PM1 $=$ Poultry manure $\left(20 \mathrm{tha}^{-1}\right), \mathrm{PM} 2=$ Poultry manure $\left(30 \mathrm{tha} \mathrm{h}^{-1}\right), \mathrm{NPK} 1=$ NPK fertilizer $\left(120 \mathrm{Kg} \mathrm{ha}^{-1}\right)$, NPK2 $=$ NPK fertilizer $\left(150 \mathrm{~kg} \mathrm{ha}^{-1}\right), \mathrm{NS}=$ Not Significant, $*=$ Significant at $5 \%$ level of probability.

Table 4. Growth parameters of red cv X. sagittifolium plants

\begin{tabular}{|c|c|c|c|c|c|c|c|c|c|c|c|c|}
\hline \multirow[b]{2}{*}{ Treatment } & \multicolumn{4}{|c|}{ Average plant height $(\mathrm{cm})$} & \multicolumn{4}{|c|}{ Average number of leaves } & \multicolumn{4}{|c|}{ Averageleafarea $\left(\mathrm{m}^{2}\right)$} \\
\hline & 2 map & 4map & 6 map & 8 map & 2 map & 4map & 6map & 8map & 2map & 4map & 6map & 8map \\
\hline Control & $23^{\mathrm{d}}$ & $41^{\mathrm{e}}$ & $50^{\circ}$ & $40^{\circ}$ & $2^{\mathrm{a}}$ & $3^{\mathrm{a}}$ & $4^{\mathrm{a}}$ & $1.5^{\mathrm{a}}$ & $0.020^{c}$ & $0.031^{\mathrm{c}}$ & $0.041^{\mathrm{c}}$ & $0.018^{c}$ \\
\hline PM1 & $29^{b}$ & $51^{\mathrm{b}}$ & $60^{b}$ & $38^{\mathrm{c}}$ & $3^{\mathrm{a}}$ & $3^{\mathrm{a}}$ & $5^{\mathrm{a}}$ & $2^{\mathrm{a}}$ & $0.027^{b}$ & $0.043^{\mathrm{b}}$ & $0.065^{\mathrm{b}}$ & $0.021^{\mathrm{b}}$ \\
\hline PM2 & $35^{\mathrm{a}}$ & $62^{\mathrm{a}}$ & $77^{\mathrm{a}}$ & $59^{a}$ & $4^{\mathrm{a}}$ & $4.3^{\mathrm{a}}$ & $5^{\mathrm{a}}$ & $3^{\mathrm{a}}$ & $0.034^{\mathrm{a}}$ & $0.054^{\mathrm{a}}$ & $0.069^{\mathrm{a}}$ & $0.031^{\mathrm{a}}$ \\
\hline NPK1 & $26^{c}$ & $46^{\mathrm{d}}$ & $55^{\mathrm{d}}$ & $38^{\circ}$ & $2^{\mathrm{a}}$ & $2.7^{b}$ & $4^{\mathrm{a}}$ & $1.3^{\mathrm{a}}$ & $0.022^{\mathrm{c}}$ & $0.028^{\mathrm{d}}$ & $0.041^{\mathrm{d}}$ & $0.011^{\mathrm{d}}$ \\
\hline NPK2 & $30^{b}$ & $48^{c}$ & $58^{\mathrm{c}}$ & $51^{\mathrm{b}}$ & $3^{\mathrm{a}}$ & $3.3^{\mathrm{a}}$ & $4.5^{\mathrm{a}}$ & $1.6^{\mathrm{a}}$ & $0.025^{\mathrm{b}}$ & $0.041^{\mathrm{c}}$ & $0.058^{\mathrm{c}}$ & $0.013^{\mathrm{d}}$ \\
\hline Significance & $*$ & $*$ & $*$ & $*$ & NS & NS & NS & NS & * & $*$ & $*$ & $*$ \\
\hline
\end{tabular}

KEY: map $=$ months after planting, PM1 $=$ Poultry manure $\left(20 \mathrm{t} \mathrm{ha}^{-1}\right), \mathrm{PM} 2=$ Poultry manure $\left(30 \mathrm{t} \mathrm{ha}{ }^{-1}\right), \mathrm{NPK} 1=$ NPK fertilizer $\left(120 \mathrm{Kg} \mathrm{ha}^{-1}\right)$, NPK2=NPK fertilizer $\left(150 \mathrm{~kg} \mathrm{ha}^{-1}\right), \mathrm{NS}=$ Not Significant, $*=$ Significant at $5 \%$ level of probability .

Table 5. Yield parameters of white cv $X$. sagittifolium plants.

\begin{tabular}{|c|c|c|c|c|c|c|}
\hline \multirow[b]{2}{*}{ Yield Parameters } & \multirow[b]{2}{*}{ Control } & \multicolumn{4}{|c|}{ TREATMENTS } & \multirow[b]{2}{*}{ Significance } \\
\hline & & PM1 & PM2 & NPK1 & NPK2 & \\
\hline Tuber number plant ${ }^{-}$ & $2^{c}$ & $4^{\mathrm{bc}}$ & $8^{a}$ & $3^{c}$ & $6^{\mathrm{ab}}$ & $*$ \\
\hline Tuber Weight (g) & $20^{\mathrm{e}}$ & $100^{\mathrm{c}}$ & $250^{\mathrm{a}}$ & $80^{\mathrm{d}}$ & $230^{\mathrm{b}}$ & $*$ \\
\hline Tuber Length $(\mathrm{cm})$ & $6^{\mathrm{c}}$ & $10^{\mathrm{b}}$ & $14^{\mathrm{a}}$ & $7^{\mathrm{c}}$ & $12^{\mathrm{ab}}$ & $*$ \\
\hline Tuber Girth (cm) & $10.5^{\mathrm{c}}$ & $13.5^{\mathrm{b}}$ & $18.5^{\mathrm{a}}$ & $11.5^{\mathrm{bc}}$ & $17^{\mathrm{a}}$ & $*$ \\
\hline
\end{tabular}

KEY: PM1 = Poultry manure $\left(20 \mathrm{t}_{\mathrm{ha}} \mathrm{a}^{-1}\right), \mathrm{PM} 2=$ Poultry manure $\left(30 \mathrm{t} \cdot \mathrm{ha}^{-1}\right), \mathrm{NPK} 1=\mathrm{NPK}$ fertilizer $\left(120 \mathrm{Kg} \cdot \mathrm{ha}^{-1}\right)$, NPK2 $=$ NPK fertilizer $\left(150 \mathrm{~kg} \cdot \mathrm{ha}^{-1}\right), \mathrm{NS}=$ Not Significant, $*=$ Significant at $5 \%$ level of probability. 
Table 6. Yield parameters of red cv X. sagittifolium plants

\begin{tabular}{lcccccc}
\hline & \multicolumn{9}{c}{ TREATMENTS } & Significance \\
\cline { 2 - 6 } Yield Parameters & Control & PM1 & PM2 & NPK1 & NPK2 & Si. \\
\hline Tuber number plant & $2.3^{\mathrm{c}}$ & $4^{\mathrm{b}}$ & $5.7^{\mathrm{a}}$ & $2.7^{\mathrm{bc}}$ & $3.6^{\mathrm{bc}}$ & $*$ \\
Tuber Weight $(\mathbf{g})$ & $22^{\mathrm{e}}$ & $52^{\mathrm{c}}$ & $124.7^{\mathrm{a}}$ & $42^{\mathrm{d}}$ & $94^{\mathrm{b}}$ & $*$ \\
Tuber Length $(\mathbf{c m})$ & $3^{\mathrm{b}}$ & $5^{\mathrm{b}}$ & $8^{\mathrm{a}}$ & $5^{\mathrm{b}}$ & $8^{\mathrm{a}}$ & $*$ \\
Tuber Girth $(\mathrm{cm})$ & $6^{\mathrm{c}}$ & $7^{\mathrm{b}}$ & $14.5^{\mathrm{a}}$ & $8^{\mathrm{b}}$ & $13^{\mathrm{a}}$ & $*$ \\
\hline
\end{tabular}

KEY: PM1 $=$ Poultry manure $\left(20 \mathrm{tha}^{-1}\right), \mathrm{PM} 2=$ Poultry manure $\left(30 \mathrm{t} \mathrm{ha}^{-1}\right), \mathrm{NPK} 1=\mathrm{NPK}$ fertilizer $\left(120 \mathrm{Kg} \mathrm{ha}^{-1}\right)$, NPK2 $=$ NPK fertilizer $\left(150 \mathrm{~kg} \mathrm{ha}^{-1}\right), \mathrm{NS}=$ Not Significant, $*=$ Significant at $5 \%$ level of probability.
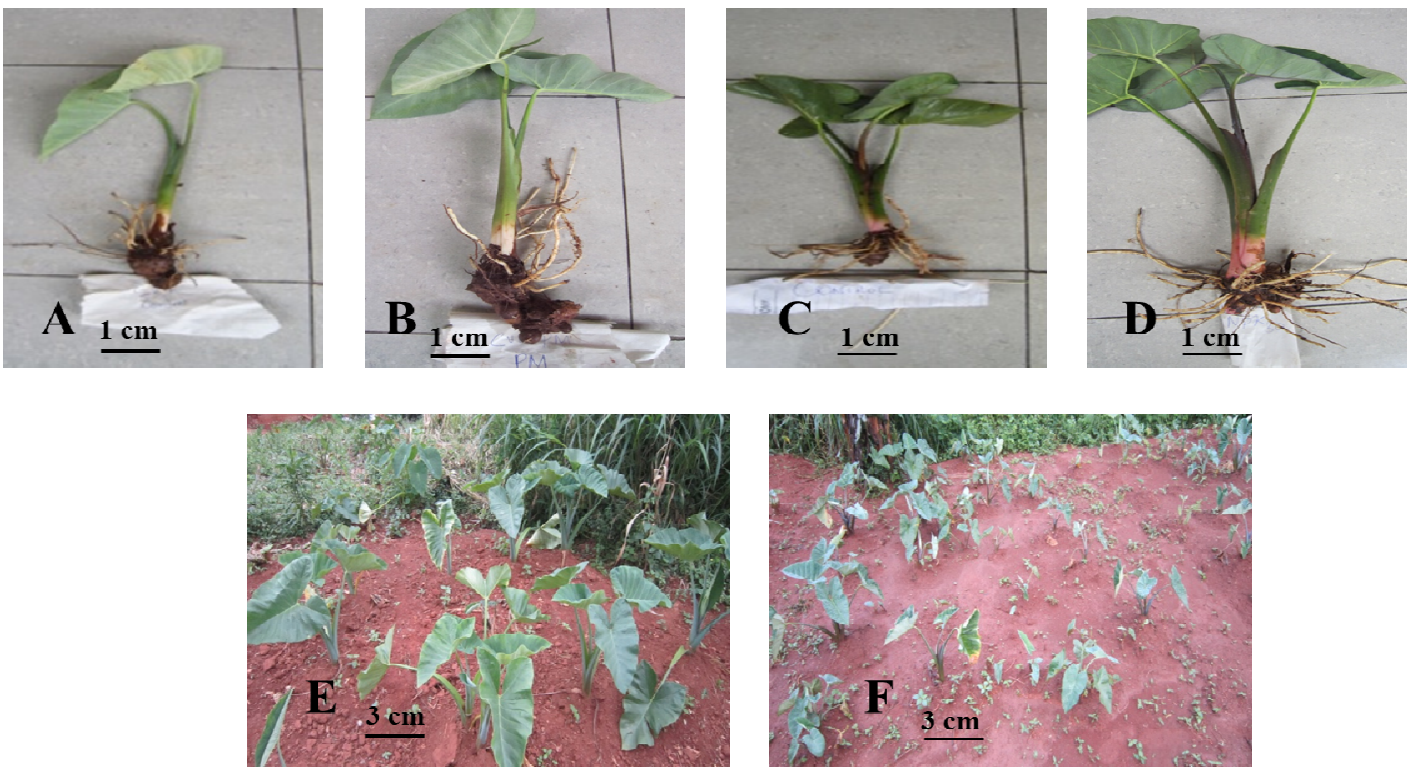

Fig.1. Aspect of cocoyam plant treatments after 6 months of growth: white cv control (A); white cv poultry manure (30tons/ha) (B); red cv control (C); red cv poultry manure (30 tons/ha) (D); white cv plot poultry manure (30tons/ha) (E); red cv plot poultry manure (30tons/ha)(F).
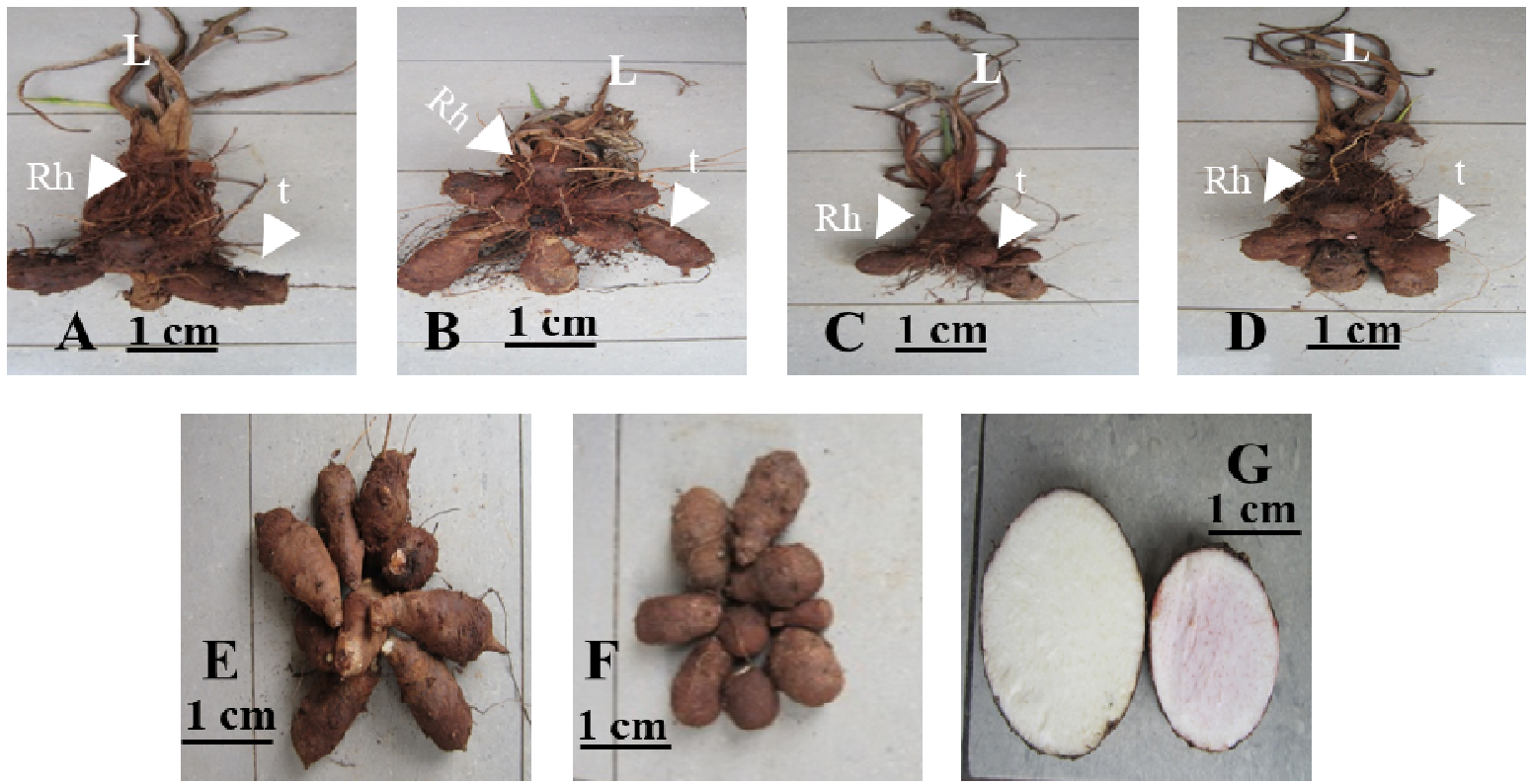

Fig.2. Aspect of cocoyam plant treatments at harvest after 9 months: white cv control (A); white cv poultry manure (30tons/ha) (B); red cv control (C); red cv poultry manure (30 tons/ha) (D); white cv tubers poultry manure (30tons/ha) (E); red cv tubers poultry manure (30tons/ha) (F); girth difference of white and red cvs $(\mathrm{G})$. Dead leaves (L), Rhizomes (Rh) and tubers (t), 

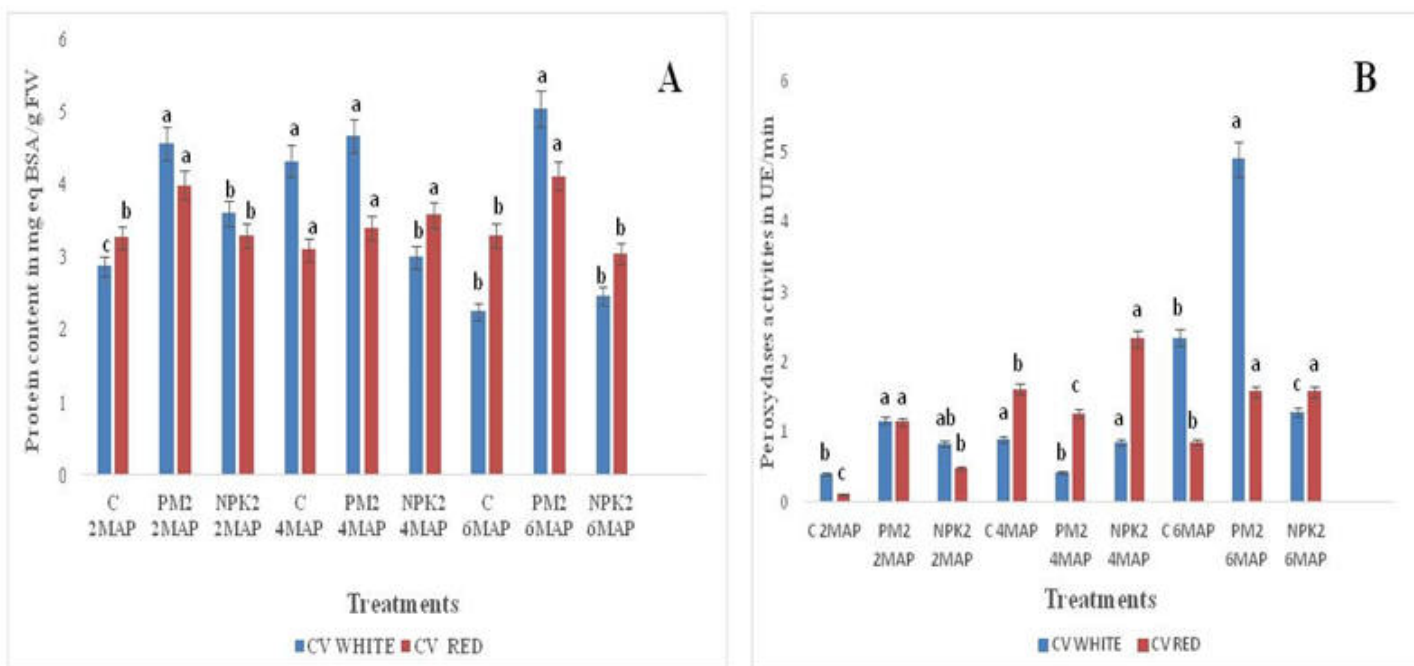

Fig.3. Protein content (mg eqBSA/FW) (A) and Peroxidase activities (UE/min) (B) in white and red cv cocoyam leaves during growth under different treatments. KEY: PM1 $=$ Poultry manure $\left(20\right.$ tons.ha $\left.^{-1}\right), \mathrm{PM} 2=$ Poultry manure $(30$ tons $/ \mathrm{ha}), \mathrm{NPK} 1=\mathrm{NPK}$ fertilizer $\left(120 \mathrm{Kg} \cdot \mathrm{ha}^{-1}\right), \mathrm{NPK} 2=\mathrm{NPK}$ fertilizer $\left(150 \mathrm{~kg} \cdot \mathrm{ha}^{-1}\right), \mathrm{MAP}=$ months after planting.
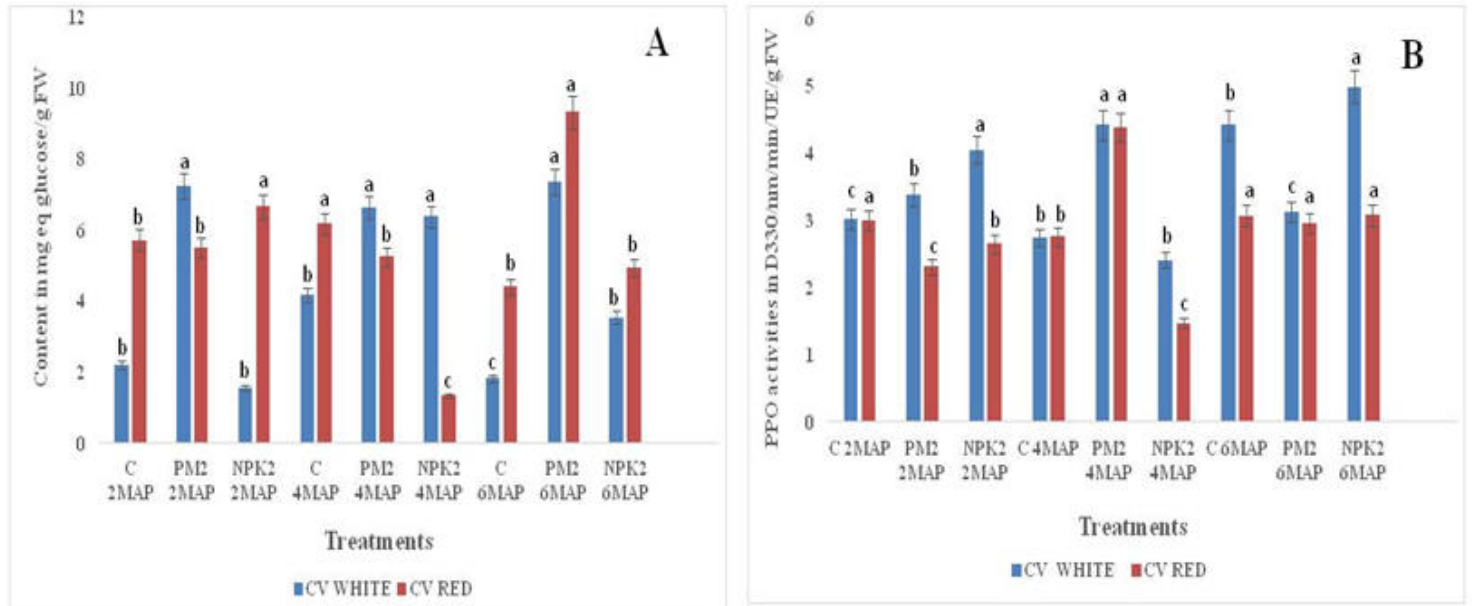

Fig.4. Glucanase activities (mg eq glucose. $\mathrm{g}^{-1} \mathrm{FW}$ ) (A) and Polyphenol oxidase activities (D330/nm/min/UE/g FW) (B) in white and red cv cocoyam leaves during growth under different treatments. KEY: PM1= Poultry manure $\left(20\right.$ tons.ha $\left.^{-1}\right)$, PM2 $=$ Poultry manure $\left(30\right.$ tons/ha), NPK1 $=$ NPK fertilizer $\left(120 K g \cdot h a^{-1}\right), N P K 2=N P K$ fertilizer $\left(150 \mathrm{~kg} \cdot \mathrm{ha}^{-1}\right), \mathrm{MAP}=$ months after planting. 

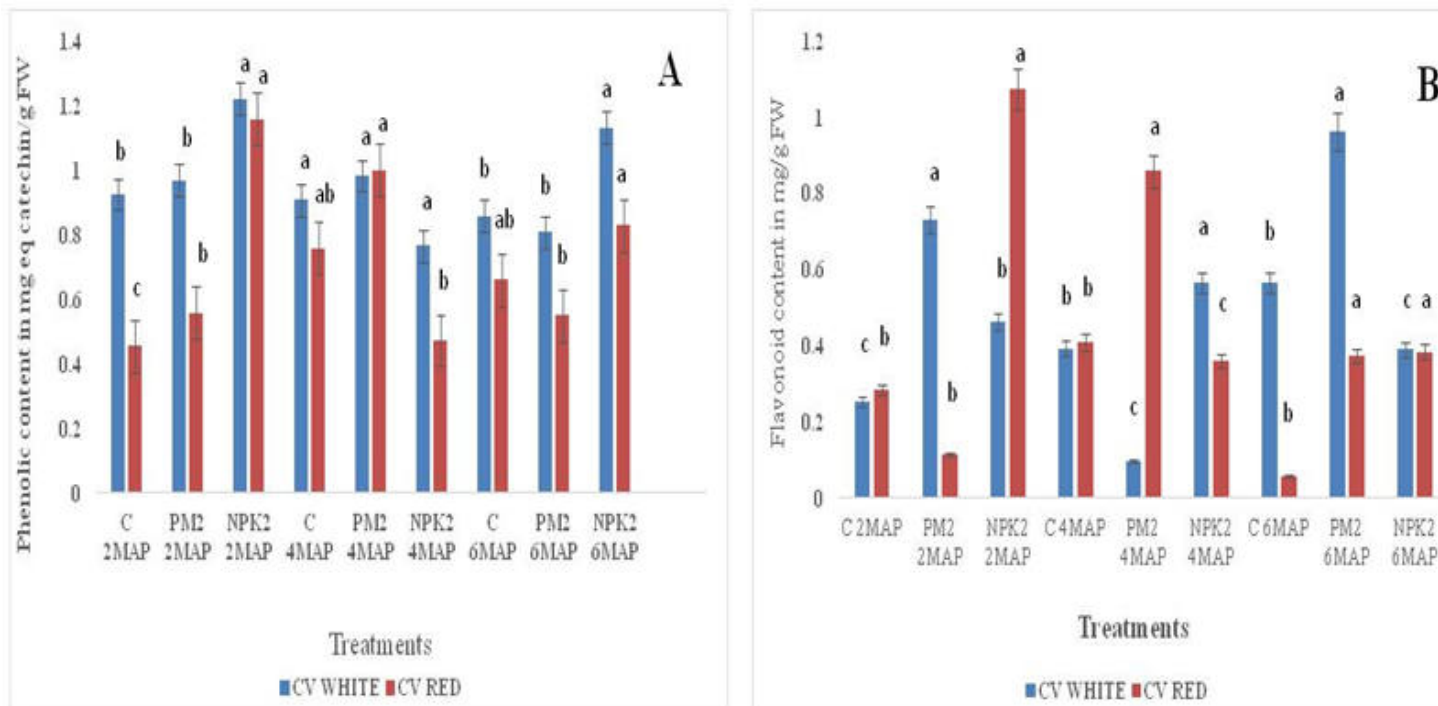

Fig.5. Phenolic content (mg eq catechin/g FW) (A) and in Flavonoid content $\left(\mathrm{mg}^{-\mathrm{g}^{-1}} \mathrm{FW}\right)(\mathrm{B})$ in white and red cv cocoyam leaves during growth under different treatments. KEY: PM1= Poultry manure (20tons.ha $\left.{ }^{-1}\right), \mathrm{PM}_{2}=$ Poultry manure $\left(30\right.$ tons/ha), NPK1 $=$ NPK fertilizer $\left(120 \mathrm{Kg}_{\mathrm{gha}}{ }^{-1}\right), \mathrm{NPK} 2=\mathrm{NPK}$ fertilizer $\left(150 \mathrm{~kg} \cdot \mathrm{ha}{ }^{-1}\right), \mathrm{MAP}=$ months after planting.

\section{DISCUSSION}

Effects of poultry manure and NPK fertilizer treatments on growth and yield parameters of the white and red cultivars of cocoyam (Xanthosoma sagittifolium L. Schott) minituber seeds were assessed. The growth and yield performance for the white cultivar cocoyam plants were significantly higher than those for the red cultivar cocoyam plants. These results are concordant with those obtained by Nzietchueng, 1985 who evaluated the production problems faced by different cocoyam (Xanthosoma) cultivars and showed that the white cultivar was more productive than the red cultivar. As observed from the results, it was evidenced that poultry manure $(30 \mathrm{t}$ $\mathrm{ha}^{-1}$ ) treatments significantly produced the highest means of traits assessed, while the control treatments of no poultry manure or no NPK fertilizer applied significantly produced the lowest means of the same traits over a 9 month growth and yield period in both cultivars. $150 \mathrm{~kg} \mathrm{ha}^{-1} \mathrm{NPK}$ fertilizer treatments expressed the most significant means of traits among all the NPK fertilizer treatments in both cultivars. Similar observations were earlier reported by Hamma et al., 2014, when they evaluated the performance of cocoyam (Colocasia esculentus.L) under the influence of organic and inorganic manure in Samaru, Zaria, Nigeria. They observed that poultry manure $\left(10 \mathrm{t} \mathrm{ha}^{-1}\right)$ produced the most significant means of growth and yield parameters among treatments of no manure (control), goat manure $\left(10 \mathrm{tha}^{-1}\right)$ and cow manure $\left(10 \mathrm{tha}^{-1}\right)$. They also showed that $150 \mathrm{~kg} \mathrm{ha}^{-1}$ NPK fertilizer treatments produced the most significant means of growth and yield traits among no NPK fertilizer (control), $90 \mathrm{~kg} \mathrm{NPK} \mathrm{ha}{ }^{-1}$ and120 kg NPK ha-1 fertilizer treatments.

The fact that these results depicted better crop performance in all parameters measured with poultry manure $\left(30 \mathrm{t} \mathrm{ha}^{-1}\right)$ than in all NPK fertilizer treatments for both white $\mathrm{cv}$ and red cv could be attributed to the fact that poultry manure treatments had a more favourable influence on soil $\mathrm{pH}$, and soil organic content by increasing them and recorded higher cation exchange capacity values than all other treatments. Similar results were obtained by Gülsüm et al., 2019 who showed that poutry manure applications improved soil organic matter content, exchangeable cations, cation exchange capacity, and percent base saturation thereby enhancing yield of sweet basil (Ocimum basilicum L.).Therefore poultry manure treatment plots retained more nutrients in the soil than the other treatments and slowly released these nutrients to the plants with reduced leaching losses of nutrients throughout the growth period Uwah et al., 2011. The chemical composition of the different treatment plots after harvest (Table2.) showed that those treated with poultry manure $\left(30 \mathrm{t} \mathrm{ha}^{-1}\right)$ had a higher $\mathrm{N}, \mathrm{K}$ and organic carbon content which could also account for better growth and yield performance. These results are similar to those obtained by Uwah et al., 2011, who evaluated the effect of organic and mineral fertilizers on growth and yield of taro (Colocasia esculenta (L.) Schott and showed that when the N,P,K and Ca contents of poultry manure increased on a site, it led to superior crop performance. Concordant results have also been obtained by Karamat et al., 2019 who showed that poultry litter had a significant increase in grain yield and N,P,K uptake by corn (Zea mays).

Protein content was most significant in white $\mathrm{cv}$ plants treated with poultry manure $\left(30 \mathrm{t} \mathrm{ha}^{-1}\right)$ after 6 months of growth. These results are contrary to those obtained by Borgmann et al., 1994 who showed that the 
total protein content decreased during the maturation of microtubers in irish potatoes. Since proteins play an important role in the growth and repair of plant cells, this could suggest a positive correlation between protein content and the different growth parameters assessed during growth of plants treated with Poultry manure (30t $\mathrm{ha}^{-1}$ ). The control and NPK2 treatments of both cultivars recorded a decrease in protein content between 4 months and 6months after planting (Fig.3), corroborating results obtained by Djeuani, 2017 obtained a decrease in leaf protein content over time especially during maturation of cocoyam minitubers.

Biotic or abiotic stress may account for the significant increase in peroxidise activity noticed in the white $\mathrm{cv}$ plants treated with Poultry manure $\left(30 \mathrm{t}^{\mathrm{h}} \mathrm{ha}^{-1}\right)$ and the during the first 6 months of growth. These results are similar with those obtained by Djocgoue,1998 ; Baaziz et al., 2006;Mas \& Heng, 2019, who showed that generally, in case of a wound, microbial infection or any other unfavourable condition, new isoperoxidases appear.

Our results also illustrate very significant levels of glucanase activities in both cultivars treated with poultry manure $\left(30 \mathrm{t} \mathrm{ha}^{-1}\right)$ after 6 months of growth. Hereby suggesting roles of glucanases in plant stress relief and agreeing with Vaiyapuri et al., 2012 who evidenced that $\beta$ 1,3 glucanases play key roles in cell division, impeding cell to cell virus movements in plants by regulating callose turnover at plasmodesmata, and withstanding abiotic stress and Xiaohui et al., 2019 who revealed the involvement of gluanases in fungal growth inhibition mechanisms by the rhizobacteria (Paenibacillus jamilae HS-26).

Polyphenol oxidases(PPOs) catalyse the oxidation of phenolic compounds into highly reactive quinones. Polyphenol oxidase activities were significant in white cv plants after 6 months of growth and in red cv plants after 4 months of growth both treated with $\mathrm{NPK}_{2}\left(150 \mathrm{~kg} \mathrm{ha}^{-1}\right)$. These results agree with Steffens et al., 1994 who suggested that in vivo polyphenol oxidase activity can be associated to senescing, wounding or damage to plant tissues in which cellular compartmentalization is lost. This is justified by the fact that classically polyphenol oxidases and their potential phenolic substrates are physically separated from one another in plants. Polyphenol oxidases are found in chloroplasts while phenolic compounds are found primarily in the vacuole and cell wall (Vaughn et al., 1998). Similarly, Ioannis et al., 2019 had results which indicated that PPOs could accept flavonoids as their natural substrates and therefore might participate in the synthetic pathways of secondary metabolites.

At 2 months after planting both cultivars treated with $\mathrm{NPK}_{2}\left(150 \mathrm{~kg} \mathrm{ha}^{-1}\right)$ recorded the most significant phenolic content values. $\mathrm{NPK}_{2}$ may have increased soil salinity, leading to the formation of large amounts of oxygen free radicals $\left(\mathrm{O}_{2} \bullet-\right)$ in peroxisomes. Accumulation of ROS results in "oxidative stress". ROS initiate free radical reactions that lead to oxidation of proteins, lipids and nucleic acids impairing their functions and causing cell death. This therefore justifies an increase in phenolic contents which form an antioxidant system developed by plants to counter "oxidative stress" by capturing ROS (Gill \& Tutejn, 2010; Sharma et al., 2012). Mas \& Heng, 2019 also depicted that total phenolic content in the extracts of Pereskia bleo leaves significantly influenced antioxidant and antimicrobial activities.

Significant flavonoid content values were recorded 6 months after planting in white cv plants and 4 months after planting in red cv plants both treated with poultry manure $\left(30 \mathrm{t} / \mathrm{ha}^{-1}\right)$. Flavonoids participate in plant protection against biotic (herbivores, microorganisms) and abiotic stresses (UV radiation, heat), and due to their antioxidative properties, they also maintain a redox state in cells. The antioxidative activity of flavonoids is connected with the structure of the molecule: the presence of conjugated double bonds and the occurrence of functional groups in the rings (Amić, et al., 2003; Seyoum et al., 2006; Ireneusz et al., 2018; Wang et al., 2019). Flavonoids reduce the production of and quench reactive oxygen species (ROS) through: suppression of singlet oxygen; inhibition of enzymes that generate ROS (cyclooxygenase, lipoxygenase, monooxygenase, xanthine oxidase); chelating ions of transition metals, which may catalyze ROS production; quenching cascades of freeradical reactions in lipid peroxidation;"re-cycling" of other antioxidants (Rice-Evans et al., 1996; Cotelle et al., 1996;Arora et al., 2000).

\section{Conclusion}

The objective of this pioneering field trial of Xanthosoma sagittifolium (white and red cultivars) minitubers as seeds was to evaluate their performance in response to different treatments of poultry manure and NPK fertilizers. Our results show that for all treatments, the white cultivar X. sagittifolium minitubers depicted better growth and yield parameters than the red cultivar minitubers. Poultry manure $\left(30 \mathrm{t} \mathrm{ha}^{-1}\right)$ stimulated the most significant responses in terms of better growth and yield among all treatments in both cultivars, suggesting that poultry manure offers a higher nutrient content and a more favourable $\mathrm{pH}$ to the soil than the other treatments. Both poultry manure $\left(30 \mathrm{t} \mathrm{ha}^{-1}\right)$ and NPK $\left(150 \mathrm{~kg} \mathrm{ha}^{-1}\right)$ treatments in both cultivars significantly influenced total soluble protein content, peroxidase activity, glucanase activity, polyphenoloxidase activity, phenolic contents and flavonoid content in the leaves during growth. These secondary metabolites play key roles in controlling abiotic and biotic stress thereby enhancing growth and development in plants. This work serves as an initial step in the improvement of cocoyam (Xanthosoma sagittifolium) production in Cameroon using cocoyam minitubers 
as seeds

\section{Acknowledgements}

The authors would like to thank the Laboratory of Plant Physiology and Biochemistry of the Higher Teachers Training college (HTTC), University of Yaoundé I, the Laboratory of Phytoprotection and Plant Valorization, Biotechnology Center, University of Yaounde I, Cameroon, for providing the equipment used in this study and the Laboratory of Soil, Plants, Water and Fertilizer Analysis IRAD Cameroon, for carrying out the soil analysis.

\section{Conflicts of Interests}

The authors have not declared any conflict of interest

\section{References}

Abd El-Latif K.M, Osman E.A.M, Abdullah R, Abd El-Kader N. (2011). Response of potato plants to potassium fertilizer rates and soil moisture deficit. Advances in Applied Science Research 2(2):388-397

Agbede T.M, Adekiya A.O., (2016). Effect of cocoa pod ash and poultry manure on soil properties and cocoyam productivity of nutrient depleted tropical alfisol. World Acad. Sci. Eng. Technol. International Journal of Biological, Biomolecular, Agricultural, Food and Biotechnological Engineering. 10(3):140-147.

Al-Moshileh, M. A. Errebhi and M. I. Motawei, (2005). Effect of various potassium and nitrogen rates and splitting methods on potato under sandy soil and arid environmental conditions. Emirates Journal of Food and Agriculture. 17 (1): 01-09.

Amić, D.; Davidović-Amić, D.; Bešlo, D.; Trinajstić, N., (2003). Structure-radical scavenging activity relationships of flavonoids. Croatica Chemica Acta, 76, 55-61.

Anele I and Nwawuisi J.U., (2008). Comparison of the effects of three pathogenic fungi on cocoyam storage. Proceedings of the $42{ }^{\text {nd }}$ Annual Conference of the Agricultural Society of Nigeria. Ebonyi State University Abakiliki, pp 183-186.

Arora A.; Byrem T.M., Nair M.G. and Strasburg G.M. (2000). Modulation of liposomal membrane fluidity by flavonoids and isoflavonoids. Archive of. Biochemistry and. Biophysique. 373: 102-109.

Baaziz M., Aissam F., Brake Z., Bendiap K., El Hadrami I. et Cheick K., (1994). Electrophoretic patterns of acid soluble proteins and active isoformes of peroxidase and polyphenoloxidase typifying calli and somatic embryos of two reputed date palm cultivar in

Baaziz M., Qacif N., Bendiab K., Aoud A., (2006). Plant peroxidases. Theoritcal aspect and practical applications. International biochemistry congress. Agadir. p17-21.

Baneerjee.A, Datta, J.K. and Mondal, N.K., (2012). Biochemical changes in leaves of mustard under the influence of different fertilizers and cycocel. Journal of Agricultural Technology 8(4): 1397-1411

Biradar RS, Venkateswarali T, Hrishi N., (1978). Leaf area estimation in Colocasia. Journal of Root Crops 4:5153.

Borgmann K, Sinha P, Frommer W.B., (1994).Change in two dimensional protein pattern and in gene expression during the sink- to-source transition of potato tubers. Plant Science 99: 97-108.

Boudjeko T., Omokolo N.D., Driouich A. and Balange P., (2005). Peroxydase and pectin ethylesterase Activities in cocoyam (Xanthosoma sagittifolium L. Schott) roots upon Pythium myriotylum Inoculation. Phytopathology 153: 409-416.

Boudjeko T., Djocgoue P.F., Nankeu J.D., Mbouobda H.D., Omokolo D.N. and EL Hadrami I., (2007). Luteolin derivatives and heritability of resistance in the Theobroma cacao L. (Cacao)/Phytophthora megakarya Bra and Griff interaction. Australasian Plant Pathology. 36: 56-61.

Bradford M.M., (1976). A rapid and sensitive method for the quantitation of microgram quantities of protein utilizing the principle of protein-dye binding. Annals of Biochemistry. 72: 248-254.

Bray RH, Kurtz L.T.,(1945). Determination of total organic and available forms of phosphorus in soils. Soil Science. 59:39-45.

Bremner JM and Mulvaney C.S.,(1982). Nitrogen-Total. In: Black CA (ed) Methods of Soil Analysis II: Soil Science Society of America. pp. 595-624.

Chandrasekara and T. Josheph Kumar, (2016). Roots and Tuber Crops as Functional Foods: A Review on Phytochemical Constituents and Their Potential Health Benefits. International Journal of Food Science Article ID 3631647, 15 pages.

Chapman H.D., (1982). Total Exchangeable Bases. In: Black CA (ed) Methods of Soil Analysis II: Madison Wisconsin. ASA (9):902-904.

Chen $\mathrm{J}$ and Adams MJ., (2001). Molecular characterization of an isolate of dasheen mosaic virus from Zantedescia aethiopica in china and comparisons in the genus Potivirus. Archives. of virology. 146:18211829.

Cotelle, N.; Bernier, J.L.; Catteau, J.P.; Pommery, J.; Wallet, J.C.; Gaydou, E.M. (1996) Antioxidant properties 
of hydroxy-flavones. Free Radical Biology and Medcine. 1996, 20, 35-43.

Djeuani AC, Mbouobda HD, Niemenak N, Fotso, Elian Hubert, et al., (2014). Effect of carbon source on minituberization of cocoyam (Xanthosoma sagittifolium): Analysis of soluble sugars and amino acids contents. Current Research in Microbiology and Biotechnology 2: 519-526.

Djeuani AC, Mbouobda HD, Fotso, Niemenak N, Omokolo ND. Improvement of Cocoyam (Xanthosoma sagittifolium L. Schott) (2017). Minitubers Production under Treatment of Glomus intraradices and Gigaspora margarita and their Impact on some Secondary Metabolite contents. Journal of Plant Science and Research. 2017;4(2): 169.

Djocgoue P.F., (1998). Analyse des variations biochimiques liées au development et à l'infection par Phytophthora megakarya Bra. Et Grif.Chez Theobroma cacao L.Thèse de Doctorat.3è cycle Université de Yaoundé I (Cameroun)., 112p.

FAO stat., (2006). Food and Agriculture Organization statistical database: World production of fruit and vegetables availablfrom http://apps.fao.org.

FAO stat., (2008). Food and Agriculture Organization statistical database: World production of fruit and vegetables available from http:/apps.fao.org.

Gee G.W and Bauder J.W., (1986). Particle Size Analysis. In: Klute A (ed) Methods of Soil Analysis I: Am. Soc. Agron. Madison W.I. pp. 91-100. Harper F (1983). Principles of Arable Crop Production. Blackwell Science Ltd.UK 8:336.

Gill SS, Tuteja N., (2010). Reactive oxygen species and antioxidant machinery in abiotic stress tolerance in crop plants. Plant Physiology and Biochemistry 2010, 48:909-930.

Giller KE, Witter E, Corbeels, M and Titonell P., (2009). Conservation Agriculture and smallholder farming in Africa: The Heretics View. Crops Research 2009. Doi:10.1016/j.fcr.2009.06.017,1-12.

Gülsüm Y, Mahmut C, Ferit Ö, Sabri A.E., (2019). Effect of Poultry Manure on Yield and Nutrient Composition of Sweet Basil (Ocimum basilicum L.). Communications in soil science and plant analysis.50: 838-852

Hamma I.L, MahmoudB.A, Wakili A, Hayatuddeen M.A., (2014). Performance of Cocoyam (Colocosia esculentus L.) as influenced by organic and inorganic manure in Samaru, Zaria, Nigeria. International Journal of Agronomy and Agricultural Research 5: 97-103.

Hota R, Jena A.K, Narayana K.L.,(2014). Effects of inorganic and organic amendments on yield of cocoyam (Colocasia esculenta) and on soil properties. World Jornal of Agricultural. Research. 2(2):70-81.

Ireneusz Go'rniak, Rafał Bartoszewski and Jarosław Kro'liczewski., (2018). Comprehensive review of antimicrobial activities of plant flavonoids. Phytochemistry Reviews. (2018) 18:241-272.

Ioannis Kampatsikas , Aleksandar Bijelic and Annette Rompel, (2019).Biochemical and structural characterization of tomato polyphenol oxidases provide novel insights into their substrate specificity. Scientific reports (2019) 9:4022 | https://doi.org/10.1038/s41598-019-39687-0.

Karamat R. Sistani, Jason R. Simmons, Marcia Jn-Baptiste and Je_M. Novak, (2019). Poultry litter, biochar, and fertilizer effect on corn yield, nutrient uptake, $\mathrm{N}_{2} \mathrm{O}$ and $\mathrm{CO}_{2}$ emissions.environments 6, 55 .

Kramling T.E. et Singleton V.L., (1969) ; An Estimate of the Non flavonoid Phenols in Wines ;American Journal of Enology and Viticulture History. 20: 86-92.

Leelasuphakul, (2006). Purification, characterization and synergistic activity of beta-1,3-glucanase and antibiotic extract from an antagonistic bacillus subtilis against rice blast and sheath blight. Enzyme and Microbial Technology. 38: 990-997.

Makinde S.O, Usilo M.I, Makinde E.A, Ayeni L.S., (2011). Comparative effect of mineral fertilizer and organic manures on growth, nutrient content and yield of Chorcorus olitorus and Celosia argentia. Reseach. Journal. of Biological. Sciences. 6:150-156.

Marigo G., (1973). On one fractioning methods and estimations of phenolic compounds in the vegetables. Analysis. 2:106-110.

Mas Athira Johari and Heng Yen Khong, (2019). Total Phenolic Content and Antioxidant and Antibacterial Activities of Pereskia bleo. Advances in Pharmacological Sciences Volume 2019, Article ID 7428593, 4 pages

Mbah C.N, Mbagwu J.S.C., (2006). Effects of animal wastes on physicochemical properties of a dystric Leptosol and maize yield in southern Nigeria. Nigerian. Journal. of Soil Science. 16:96-103

Mclean E.O., (1982). Soil PH and Lime Requirement. In: Page AL, Miller RH, Keeney DR (ed) Methods of Soil Analysis. II. American. Society of Agronomy. Madison W.I. pp. 199-124. Morocco. Euphytica. 76: 159-168.

NPRT stat., (2013).Ministry of agriculture and rural development, Yaounde, Cameroon.

Nzietchueng S., (1985). Genre Xanthosoma (macabo) et contraintes de production: cas particulier de la pourriture racinaire causée par pythium myriothylum au Cameroun. Thèse d'Etat.Université de Yaoundé., $253 \mathrm{p}$.

Obigbesan G.O.,(1980). Potassium responses in root and tuber crops. In: Potassium Workshop held in October. at IITA, Ibadan. 
Ogbonna PE, Nwaeze N.J., (2012). Evaluation of growth and responses of cocoyam (Colocasia esculenta) cultivars to rates of NPK 15:15:15 fertilizer. African. Journal. of Agricultural. Research. 7(49):6553-6561.

Ojeniyi S.O., (2000). Effect of goat manure on soil nutrient and okra yield in a rain forest area of Nigeria. Applied. Tropical. Agriculture. 5:20-23.

Ojeniyi S.O, Amusan O.A, Adekiya A.O.,(2013). Effect of poultry manure on soil physical properties, nutrient uptake and yield of cocoyam (Xanthosoma sagittifolium) in South west Nigeria. American-Eurasian Journal. of Agricultural. and Environmental. Sciences. 13(1):121-125.

Omokolo N.D., Boudjeko T., Tsafack T., (2003). In vitro tuberization of Xanthosoma sagittifolium (L.) Schott: effects of phytohormones, sucrose, nitrogen and photoperiod. Scientia. Horticulturae. 98: 337-345.

Onopkise O.U., Wutoh J.C., Ndzana X., Tambong M., Mekoba, Sama A.E., Nyochembeng A., Aguegia S., Nzietchueng J.G., Burns M., (1999). Evaluation of cocoyam germplasm in Cameroon. In: J.Janick perspectives of new crops and new uses, ASHS Press, Alexandria. VA.,p 339-396.

Perneel M., Tambong J.T., Abiobo A., Floren C., Saborio F., Leveque A., Hofte M., (2006). Intraspecific variability of pythium myriotylum isolated from cocoyam and the other host crops. Mycological Research. 110: 583-593.

Pirovani C.P., Carvalho H.A., Machado R.C. et Gomes D.S., (2008). Protein extraction for proteome analysis from cacao leaves and meristems, organs infected by Moniliophthora perniciosa, the causal agent of the witches' broom disease. Electrophoresis.29: 2391 -2401.

Rice-Evans, C.A.; Miller, N.J.; Paganga, G. (1996) Structure-antioxidant activity relationships of flavonoids and phenolic acids. Free Radical. Biology. and Medicine. 20, 933-956.

Sanchez P.A, Jama B.A, (2002). Integrated Plant Nutrient Management in Sub-Saharan Africa: From Concept to Practice, Vanlauwe B, Diels J, Sanginga N, Merckx R, Eds. (CABI, Wallingford, UK, pp. 23-45; P. A.

Sefa-Dedeh S and Agyir- Sackey K.E., (2004). Chemical composition and effects of processing on oxalate content of cocoyam Xanthosoma sagiittifolium and colocasia esculenta cormels. Food chemistry.,85,p.479487.

Seyoum, A.; Asres, K.; El-Fiky, F.K., (2006). Structure-radical scavenging activity relationships of flavonoids. Phytochemistry 2006, 67, 2058-2070.

Sharma P, Jha AB, Dubey RS, Pessarakli M., (2012). Reactive Oxygen Species, Oxidative Damage, and Antioxidative Defense Mechanism in Plants under Stressful Conditions. Journal of Botany 2012, Article ID 217037:1-26. doi:10.1155/2012/217037.

Steffens J.C, Harel E, Hunt M.D.,(1994) Polyphenol oxidase. In BE Ellis, ed, Genetic Engineering of Plant Secondary Metabolism. Plenum Press, New York, pp 275-312.

Stoorvogel JJ, and Smaling E.M.A., (1990). Assessment of soil nutrient depletion in sub- Saharan Africa: $1983-$ 2000 .

Suge J.K, Omunyin M.E, Omami E.N., (2011). Effects of organic and inorganic sources of fertilizer on growth, yield and fruit quality of eggplant (Solanum melongena L.). Archives. Applied. Science. And Research. $3(6): 470-479$.

Tugba B.O, Omer E, Oktay Y, Ali B, Meryem K, Huseyem S, and Mustafa K., (2014). The Effect of Different Manures and Synthetic Fertilizer on biochemical and antimicrobial Properties of Mentha piperita L. DOI: $10.1111 / \mathrm{jfbc}$.

Ubalua,A.O and Chukwu, L.I., (2008). Potentials and constraints of cocoyam production in Nigeria. Proceedings. 42 $2^{\text {nd }}$ Annual. Conference. Of the Agricultural. Society. of Nigeria. Ebonyi State University Abakiliki, pp 298-302.

Uwah D.F., Udoh A.U., Iwo G.A., (2011). Effect of organic and mineral fertilizers on growth and yield of Cocoyam (colocasia esculenta (1.) schott). International Journal of Agriculture Sciences. Vol. 3, Issue 1, 2011, PP-33-38.

Vaiyapuri Balasubramanian ., Divya Vashisht .Jean Cletus ., Natarajan Sakthivel (2012). Plant $\beta-1,3-$ glucanases: their biological functions and transgenic expression against phytopathogenic fungi. Review. Biotechnology Letters (2012) 34:1983-1990.

Van Kammenn A. et Broumer D., (1964). Increase of polyphenoloxidase activity by a local virus infection in uninoculated leaves. Virulogy. 22: 9-14.

Vaughn K.C, Lax AR, Duke S.O., (1988). Polyphenol oxidase: the chloroplast oxidase with no established function. Physiologia Plantarum 72: 659-665.

Wang X, Li C, Zhou Z and Zhang Y., (2019). Identification of three (Iso)flavonoid Glucosyltransferases from Pueraria lobata. Frontiers in Plant Science. 10:28. doi: 10.3389/fpls.2019.00028.

Xiaohui Wang, Qian Li, Junkang Sui, Jiamiao Zhang, Zhaoyang Liu, Jianfeng Du, Ruiping Xu, Yanyan Zhou, and Xunli Liu, (2019). Isolation and characterization of antagonistic bacteria Paenibacillus jamilae HS-26 and their effects on plant growth. BioMed Research International Volume 2019, Article ID 3638926, 13 pages. 